\title{
Dampak Sosial Politik terhadap Perkembangan Ekonomi Umat Allah Zaman Perjanjian Lama
}

\author{
Karel Martinus.Siahaya \\ Sekolah Tinggi Agama Kristen Teruna Bhakti Yogyakarta \\ karelsiahaya@yahoo.co.id
}

\begin{abstract}
This is a study of the Old Testament about the economic development of the Old Testament Israelites which was influenced by several things such as social politics. The purpose of this discussion is to show the social, potent and even geographical influences on the economic development of the people. By using descriptive methods, the conclusion obtained from this study is, political power will have an impact on the economic development of the people in it. Likewise with social, there is a development of social structures based on the economy.
\end{abstract}

Keywords: Old Testament economics; Old Testament; social politics of the Old Testament

\begin{abstract}
Abstrak: Ini adalah sebuah kajian Perjanjian Lama tentang perkembangan ekonomi umat Israel zaman Perjanjian Lama yang dipengaruhi oleh beberapa hal seperti sosial politik. Tujuan pembahasan ini adalah untuk menunjukkan pengaruh sosial, potik, bahkan geografi terhadap perkembangna ekonomi umat. Dengan menggunakan metode deskriptif, kesimpulan yang diperoleh dari kajian ini adalah, kekuasaan politik akan memberikan dampak bagi perkembangan ekonomi umat di dalamnya. Demikian juga dengan sosial, terjadi perkembangan struktur sosial berdasarkan ekonomi.
\end{abstract}

Kata Kunci: ekonomi Perjanjian Lama; Perjanjian Lama; sosial politik Perjanjian Lama

\section{Pendahuluan}

Umat Kristen pada umumnya dapat menerima Alkitab Perjanjian Baru (PB) dengan mudah karena Alkitab PB adalah dokumen yang memberi kesaksian tentang kehidupan, kematian dan kebangkitan dan pengajaran Kristus yang penuh kuasa serta sejarah pendirian gerejaNya. Namun, agak berbeda dengan Perjanjian Lama (PL). Perjanjian ini dianggap sulit untuk dipelajari. Mempelajari PL merupakan bagian yang sangat menyenangkan jika dilengkapi dengan pemahaman dan pengetahuan mengenai situasi pada masa itu. Di dalam paper ini, disajikan bagaimana perkembangan Sosial Politik dan Ekonomi umat Allah Zaman Perjanjian Lama.

\section{Dunia Perjanjian Lama}

\section{Perkembangan Sosial}

Sebagian besar Perjanjian Lama ditulis dalam bahasa Ibrani, sedangkan bahasa Aram digunakan dalam beberapa bagian teks PL kemungkinan di masa pembuangan yakni Ezra 4:8-6-18; 7:12-26; Yeremia 10:11; dan Daniel 2:4-7:28. Bahasa Ibrani dan Aram 
digolongkan dalam rumpun Bahasa Semit yang terletak Asia Barat (Timur Tengah). Istilah Semit diambil dari nama anak Nuh yakni Sem. Jadi Semit adalah keturunan Sem yang dianggap nenek moyang bangsa-bangsa Timur Tengah sesuai dengan tulisan Musa dalam kitab Kejadian. Dalam rumpun bahasa yang sama terdapat juga bahasa Arab. Semua bahasa Semit ditulis dari kanan ke kiri, sesuai dengan kebiasaan pada zaman kuno. ${ }^{1}$

Perlu juga memperhatikan geografis atau dunia Perjanjian Lama. Penyataan Allah terjadi dalam ruang dan waktu, sehingga penafsiran yang tepat mengharuskan penafsir di zaman sekarang harus memperhatikan data geografis, historis, dan teks. Dunia yang dikenal pada zaman PL hampir sama dengan daerah yang disebut Timur Tengah. Secara geografis, merupakan tanah yang subur (tidak terhitung padang pasir) yang sering disebut Sabit yang Subur karena berbentuk sabit dengan luasnya kira-kira 400000 KM2. Dari informasi ini didapatkan data bahwa jarak Mesopotamia-Kanaan-Mesir (perjalanan Abraham) sekitar $2000 \mathrm{KM}^{2}$

Tokoh-tokoh utama dalam PL pada umumnya hidup di Palestina, tetapi pada saat tertentu hidup di luar Palestina seperti daerah Mesopotamia atau Mesir. Kadang-kadang disebutkan pula tentang orang-orang dari persia, Arab Selatan, Etiopia Asia Kecil, pulaupulau Laut Tengah Yunani, dan daerah-daerah lain. Dalam Alkitab, keadaan alam mempunyai makna teologis. Allah menjadikan daratan dan menahan laut. Ia membuat tanah mengeluarkan hasilnya atau mengirim bencana kelaparan, Ia mengirim atau menahan hujan. Ia membuat bangsa-bangsa berpindah-pindah dari satu tempat ke tempat lain, membawa orang Israel dari Mesir, orang Filistin dari Kaptor, dan orang Siria dari Kir (Amos 9:2).

Mungkin pemahaman teologis mengenai keadaan geografis paling jelas terlihat pada saat nabi-nabi berjuang melawan Baal. Ketika Israel memasuki tanah perjanjian, mereka berhubungan dengan agama Kanaan, suatu agama pemuja alam yang berpusat pada Baal. Dalam agama Israel ditegaskan bahwa Tuhan Allahlah yang memberi upah, minyak, air anggur dan meningkatkan jumlah ternak (Hos 2:8). Baal adalah ilah yang sangat duniawi dan pemujaan Baal mencakup pelacuran seksual untuk membujuk tanah agar mengeluarkan hasilnya. Karena itu nabi-nabi Israel menentang keras pemujaan Baal dengan keyakinan bahwa Tuhan Allahlah yang menciptakan dunia, memberi atau menahan hasil. $^{3}$

Keadaan geografis dan iklim biasanya menjadi bagian penting dari pemberitaan para nabi. Jika kita ingin mengerti Firman Allah sebagaimana diberitakan oleh para nabi, maka kita memerlukan pengetahuan dasar tentang keadaan geografis, karena rincian unsur-unsur geografis dan iklim menjadi bagian dari bahasa yang dipakai Allah dalam penyataan-Nya.

Hal lain yang tidak kalah penting adalah strata dalam masyarakat Perjanjian Lama. Sekalipun tidak ditonjolkan, ada perbedaan kelas-kelas dalam masyarakat PL, khususnya

\footnotetext{
${ }^{1}$ David L. Baker, Mari Mengenal Perjanjian Lama, (Jakarta, PT. BPK Gunung Mulia, 2004), 15

${ }^{2}$ LaSor dkk., Pengantar Perjanjian Lama 1 (Jakarta, PT. BPK Gunung Mulia, 2002), 75-89

${ }^{3}$ David L. Baker, Mari Mengenal Perjanjian Lama, 231-232
} 
setelah zaman kerajaan terbentuk. Perbedaan antara mereka yang kaya dan miskin menjadi sangat nyata. Beberapa orang mendapat penghasilan dari tanah yang berlebihan dan akhirnya menjadi kaya. Tapi ada juga yang karena melakukan praktik- praktik yang tidak adil sehingga menekan pihak lain untuk mendapatkan keuntungan, sehingga mereka yang tidak diuntungkan menjadi miskin. Berikut ini adalah perbedaan strata dalam masyarakat PL secara umum: ${ }^{4}$

Pertama ada kelompok masyarakat yang berpengaruh. Mereka adalah para tua-tua agama dan kepala rumah tangga. Setelah zaman kerajaan, muncul kelompok yang disebut sebagai para pemuka, yaitu pembantu-pembantu raja dan juga para pahlawan. Kemudian, ada penduduk asli setempat. Mereka yang memiliki tanah dan tinggal sebagai penduduk asli di Palestina. Selain itu ada penduduk asing. Mereka adalah pendatang dan orang bebas (bukan budak) tetapi tidak memiliki hak penuh sebagai warganegara Palestina. Pekerja upahan adalah mereka yang tidak memiliki tanah, hidup sebagai tenaga upahan. Pedagang adalah orang-orang asing yang datang untuk berdagang. Dan terakhir ada budak-budak. Mereka bukan hanya orang Israel saja (yang miskin), tetapi juga pendatang asing yang hidup sebagai tawanan perang. Perbudakan adalah salah satu kebiasaan cara hidup pada masa PL.

\section{Politik dalam Perjanjian Lama}

Politik Perjanjian Lama dmulai dari kekuasaan di Mesopotamia. Mesopotamia adalah daerah yang terbentang dari sungai Tigris hingga sampai sungai Eufrates. Kitab Suci menyebutnya sebagai Mesopotamia. Daerah sepanjang sungai yang terbentang ini merupakan daerah yang subur, penghasil makanan dan kayu , jalur perdagangan (terutama perdagangan tekstil). Dengan pencapaian itu, maka Mesopotamia merupakan suatu daerah yang cukup dikenal di dataran timur tengah. Mesopotamia tumbuh sebagai bangsa yang maju, penduduk mampu memelihara berbagai hewan ternak dan juga mengenal tulisan dalam bentuk piktografi (cerita yang digambarkan dalam bentuk visual). Piktografi merupakan gerbang awal dalam sistem penulisan bagi penduduk disana, piktografi juga merupakan awal dari tulisan Hittile dan Ugarith.

Perkembangan itu juga terjadi dalam bidang politik, pada zamannya, Mesopotamia sudah menggunakan sistem politik modern. Kekuasaan politik tidak terletak di tangan raja cara mutlak, melainkan terletak di tangan para pemimpin lokal yang tersebar di perkampungan yang terpisah satu sama lain. Hal diatas dibuktikan dalam gilgamesh dan angga yang keduanya adalah syair yang terkenal pada 3000SM. Bukan hal itu saja, pemimpin perkampungan itu secara rutin juga sering berkumpul bersama, perkumpulan ini pun disebut dewan umum (rapat umum). Sementara pemimpin perkampungan disebut penatua atau sesepuh.

${ }^{4}$ J.I Packer, Merrill C. Tenney, William White, Jr. Ed., Ensiklopedi Fakta Alkitab II (Malang: Gandum Mas, 2001)357-366 
Sistem demokrasi di Mesopotamia jugalah sangat baik. Di dalam kawasan tersebut muncul tingkat keadilan dan sistem yang egaliter (sama derajat). Hal inipun sungguh dipraktekkan walaupun pemilihan pemimpin masih bersifat primitif dengan berdasarkan usia, kemampuan magis, kemampuan dalam bidang mitos-puitis dan lain syarat.

Keadilan dan perlindungan terhadap hak warga (terutama warga kecil) juga menonjol. Hal ini sangat terlihat dalam syair-syair Sumeria. Dalam syair ada gambaran tentang Dewa Utu yang dianggap dewa matahari dan dewa keadilan. Dewa Nanshe sebagai dewa keadilan yang sangat peduli dengan rakyat tertindas, orang miskin , janda , yatim piatu. Dungi, dewa yang dipuji dan dihormati karena jasanya melindungi dan dan menolong orang papa dan orang miskin. Muncul juga madah dan pujian yang memperlihatkan keadilan dan kebebasan rakyat sebagai sebuah pilar utama dalam kerajaan, jika keadilan dan kebebasan itu runtuh maka kerajaan (dan juga negara) juga runtuh dengan sendirinya. Dalam bentuk yang lebih legalistis, keadilan sangat dipraktekkan di Mesopotamia, dibuktikan dengan Undang-Undang Ur-Nammu yang berbicara tentang keberpihakan terhadap orang miskin. Undang-Undang Lipit-Ishtar yang berbicara tentang menegakkan keadilan yang dimulai dengan memberantas korupsi. Undang- Undang Echununna yang berbicara tentang penetapan harga dasar kebutuhan pokok agar ekonomi semua warga terpenuhi. Undang- Undang raja Hammurabi yang menindak tegas para hakim dan pejabat yang korup dan membawa keadilan bagi yatim piatu dan para janda. Surat keputusan Ammi- Tsaduqa yang ingin memulihkan keadaan ekonomi negara karena turunnya pendapatan perkapita rakyat sehingga menimbulkan hutang piutang.

Kemudian ada kekuasaan di Mesir. Mesir mulai dikenal ketika raja Firaun menjadi raja atas Mesir. Nama Firaun berasal dari kata per dan aa yang berarti Rumah Besar. Ia bertekad untuk menciptakan tempat hunian yang nyaman dan damai bagi semua penduduk Mesir.

Pada Millenium ketiga, sistem kekuasaan sudah mulai dibagikan. Raja tidak lagi memerintah sendirian melainkan kekuasannya itu dibagikan kepada anggota keluarganya. Menjelang akhir millenium ketiga, kekuasaan itu tidak dibagikan kepada anggota keluarga raja melainkan kepada para bangsawan. Dalam waktu itu, sistem pembagian tugas yang tegas sudah terjadi dan mulai dipraktekkan seperti misalnya pembentukan perdana menteri, para menteri dan pegawai kerajaan. Sistem birokrasi macam ini dipimpin oleh seorang tukang mimpi. Tukang mimpi memiliki tugas yakni melihat hubungan keberadaan kerajaan dan juga raja dengan dewa-dewi atau melihat masa depan kerajaan. Kejadian 41-47 menegaskan bahwa Yusuf merupakan salah satu tukang mimpi yang melaksanakan tugas tersebut.

Salah satu nilai sejarah politik yang ditinggalkan oleh dinasti firaun adalah ajaran dan pepatah. Salah satu pepatahnya dari tahun 2450 SM yang menegaskan tentnag keadilan. Keadilan adalah bersifat kekal abadi, semua boleh berakhir namun keadilan tetap bertahan dalam keabadian. Nyatanya, praktek keadilan belum berjalan mulus. Perbudakan dan 
ketidakadilan masih menonjol. Pembangunan piramida, pembersihan tanggul, kanal, irigasi menuntut suatu jumlah tenaga kerja yang besar, dan hal ini dilakukan oleh para budak.

Piramida dalam tradisi Mesir merupakan simbol dari masyarakat mesir sendiri, dimana kelas struktur masyarakat berpuncak pada diri seorang raja dan raja berkuasa mutlak. Jadi yang paling puncak adalah raja sementara rakyat jelata adalah landasan yang harus menopang keberadaan kelas atas.

Keadilan pada rakyat berjalan mulus dalam pemerintahan raja Firaun dibuktikan dengan kisah Oasian (2000 SM) tentang petani yang dirampok oleh seorang kaya, dan diproses dalam pengadilan sehingga akhirnya sang petani diputuskan menjadi pemenang sementara orang kaya dijadikan hamba oleh petani untuk membayar kesalahannya. Kisah ini dikenal luas di daerah Mesir dan Palestina. Karena kisah inilah, nabi Amos mendapatkan inspirasi untuk mewartakan keadilan di Palestina. Kisah ini mengajarkan bahwa kebersamaan hidup dengan orang lain menuntut keadilan dan solidaritas sosial yang ikhlas. Orang kecil dan sederhana tidak boleh dibodohi atau dimanipulasi oleh siapapun.

\section{Pembahasan}

Ada tiga fase sejarah politik Israel; masa prakerajaan, masa kerajaan dan masa poskerajaan. Israel memanglah ditakdirkan sebagai suatu kesatuan yang etnis-politis, bukan sebagai kesatuan religius. Walaupun pada prakteknya, di dalam pandangan orang Israel selalu hidup di bawah pengawasan Allah sehingga muncul ketakutan yang timbul akan dosa kalau suatu saat menghadapi Allah yang murni dan suci (Kejadian 3:8, 24). ${ }^{5}$

\section{Israel Kuno}

Secara historis, peristiwa keluarnya dari Mesir dilihat sebagai suatu pembebasan dari perbudakan. Walaupun dalam laporan sejarah, peristiwa itu tak pernah dicatat namun bagi Israel, peristiwa itu adalah sebuah teror yang ingin memperlihatkan betapa takutya bangsa Israel. (Kel 14:5-9), dan mereka meyakini bahwa pembebasan itu benar-benar datang karena bantuan Yahweh (Kel 14:14).

Pembentukan kerajaan Israel lahir sebagai suatu masyarakat yang terpisah. Masyarakat yang berpisah itu disebabkan oleh penderitaan bersama (karena dijajah oleh Mesir) dan karena adanya tekanan dari luar. Kehidupan suku-suku Israel mempunyai sistem familier. Dari konsep ini yang pertama kali menjadi hukum Israel sebagai tuntutan kesetaraan dan solidaritas yang praternal, solidaritas karena merasa saling bersaudara. Solidaritas ini benar-benar diuji di tengah kehidupan nomaden karena kerasnya hidup di padang gurun dan persaingan suku. Di lain sisi, solidaritas menjadi jaminan juga agar orang dapat hidup di tempat tertentu dengan nyaman.

Sebagai suku yang semi-nomaden dan sistem familier, Israel mempunyai kepekaan khusus terhadap keadilan. Para hakim yang adalah pemimpin kharismatik dapat memimpin masyarakat. Secara lebih khusus, mereka dapat menghubungkan suku-suku dalam suatu

\footnotetext{
${ }^{5}$ Rm. Dr. Matius Mali, CSSR, Konsep Berpolitik Orang Kristiani, (Yogyakarta: Kanisius Media, 2014)
} 
interaksi sosial tertentu. Mereka juga dapat mempraktekkan suatu kekusaan politis yang dianggap tepat dalam masyarakat, walaupun dalam waktu tugas yang singkat.

Aspirasi yang mendasar bagi suku-suku yang bersatu adalah membela kemerdekaan dan membela diri dari ancaman luar serta memberi sumbangan tertentu bagi hidup bersama dan tidak mempraktekkan kekerasan. Seluruh hak mereka haruslah dijamin oleh tempat/ komunitas dimana ia hidup dimana setiap anggota memiliki hak dan kewajiban yang sama. Kekuasaan yang dilegitimasi Yahweh hanya pada kasus peperangan untuk mempertahankan identitas diri orang Israel. Semua orang Israel wajib membela tanah airnya bila mendapat ancaman dari luar.

\section{Masa Kerajaan}

Ketika kembali ke Mesir , bangsa Israel menetap di Palestina dan menjadi tuan tanah. Hidup mereka tak lagi berpindah (nomaden / semi nomaden) melainkan sudah menetap karena Yosua telah membagikan tanah bagi mereka semua (Yos 18:1-10). Dalam pembagian tanah ini, timbul berbagai permasalahan karena tanah bisa menjadi lahan ekonomis. Hal inilah yang membuat solidaritas fraternal menjad luntur (Im 25:23). Perlu diingat bahwa seharusnya kepemilikan tanah adalah milik suku, bukan secara pribadi.

Orang Israel hidup berdampingan dengan orang kanaan asli (Amori). Gaya hidup kanaan didominasi oleh kelompok kecil yang mempunyai hak khusus akan perekonomian, pemerintahan dan agama. Mereka juga menjualkan tanahnya secara bebas, termasuk kepada orang Israel. Orang Israel membeli tanah dari kanaan melalui lembaga finansial, maka tanah itu secara resmi milik suku/keluarga dari bangsa Israel. Dalam bangsa Israel , menjual tanah adalah haram, maka mereka haruslah mempertahankan dan mewariskan tanah itu turun temurun karena menganggap bahwa warisan tidak boleh diperjualbelikan (Bil 26:53).

Karena bangsa Israel ingin seperti bangsa-bangsa yang lain (1 Sam 8:5), muncullah Daud dan Salomo sebagai pilar keinginan bangsa Israel. Raja dan negara dengan para fungsionaris dan tentara memegang peranan penting dalam menjalankan kekuasaan politik. Namun pada zaman yang berbeda, muncullah Daud. Daud memunculkan pemikiran yaitu adanya kesatuan teritorial yang penduduk dari suku lain (Kanaan, Edom, Moab). Pada saat zaman itu, Raja merangkum seluruhnya di dalam dirinya; kekuasaan politik, militer, yuridis, religius. Raja adalah penanggung jawab dan pemegang supremasi tertinggi sebagai raja Israel. Kekuasaan raja benar-benar dilihat sebagai perpanjangan tangan Yahweh. Sebobrok apapun dosa raja, raja akan selalu dimaafkan oleh rakyatnya karena raja dapat bertindak apa saja. (1 Sam 8:10-20).

Adanya raja berimplikasi adanya kekuasaan. Kekuasaan itu berarti mendominasi seseorang atau dapat menekan seseorang agar dapat mengikuti kehendak penguasa. Kekuasaan dalam diri raja berarti penguasaan. Hal ini tidak sesuai dengan semangat asali (dasar) keberadaan suku Israel yang berpedomankan kemerdekaan, kesetaraan dan kekeluargaan. 
Para nabi sangat kritis tentang pembagian masyarakat ke dalam kelas sosial dan juga penggunaan kekerasan dalam pelaksanaan kekuasaan. Para nabi mengkritik secara keras bagi raja dan masyarakat yang hanya memikirkan hanya soal kekuasaan politik, ekonomi, militer. Para nabi juga berpendapat bahwa kekuasaan, harta benda dan militer dapat menjerumuskan orang pada sikap anti Allah. Orang merasa diri bisa mendapatkan segalanya dengan hasil usahanya sendiri. Sikap diri yang seperti itu akan mendorong orang untuk menjadi otoriter, sikap yang melibas semua orang yang menghalangi rencananya.

Pihak raja dan para pegawainya terjadi politik pencitraan diri. Raja memegang peranan penting dalam suatu wilayah, walaupun politik pencitraan diri harus terjadi. Hakim 21:25 menyatakan bahwa ketidakhadiran raja membuat kehancuran bangsa Israel, yaitu setiap orang berbuat apa yang benar menurut pandangannya sendiri. Hakim 19 merefleksikan bahwa untuk menciptakan suatu fondasi yang kuat dalam kerajaan dibutuhkan peran raja. Dengan demikian, kerajaan dan raja dibutuhkan untuk mengatur keadaan yang kacau balau. Pendirian kerajaan dan pemilihan raja seolah-olah diperlukan orang israel agar hidup mereka lebih teratur. Karena itu ideologi seperti hal diatas dipublikasikan secara besar.

\section{Setelah Pembuangan}

Sekalipun peristiwa pembuangan Babel dilihat sebagai sesuatu yang menyakitkan, melalui pengamatan luar rupanya juga memberikan kontribusi berharga dalam perkembangan peradaban keagamaan serta politik dan identitas Yahudi. Trauma selama pembuangan, situasi krisis identitas, membuat mayoritas dari komunitas tersebut agak tertutup terhadap orang lain, bahkan tertutup juga dengan anggota komunitas mereka sendiri yang memilih untuk berbaur bersama bangsa lain. Etnisitas kolompok segera menjadi tanda untuk mengenali satu sama lain, antara mereka dengan bangsa lain ataupun antara mereka dengan komunitas mereka sendiri yang memutuskan untuk melebur dengan kebudayaan orang asing.

Nama Yahudi muncul pada masa ini, dan Yudaisme sebagai sistem keagamaan yang berkembang untuk menerangkan identitas kebangsaan-keagamaan mereka. Peristiwa pembuangan mendorong minat mayoritas bangsa Israel untuk melihat kembali arti perjanjian yang diadakan Allah bersama mereka. Mereka kembali melirik dengan lebih serius Kitab Suci agama mereka, secara menyeluruh Kitab Taurat, sejarah, sastra dan tulisan para nabi terdahulu untuk mempertegas siapa diri mereka selama berhadapan dengan masa krisis itu. Pengumpulan dan penyusunan Kitab-kitab Suci, menjadi kebutuhan yang mendesak selama berada di pembuangan. Memang secara historis diketahui bahwa pembuangan Babel hanya terjadi selama kurang lebih 50 tahun, akan tetapi melalui nubuatan Yeremia dapat diketahui bahwa setidaktidaknya peristiwa pembuangan itu direfleksikan Israel terjadi selama kurang lebih tujuh puluh tahun, baru Allah mengembalikan kejayaan Israel (Yer 25:11; 29:10). 
Setelah 50 tahun berlalu, munculah seorang Raja bernama Koresy yang memberikan kemungkinan bagi orang Yahudi untuk kembali ke Palestina. David F. Hinson dalam tulisannya mengatakan bahwa Koresy dan tentaranya berhasil mengalahkan tentara Babelonia dalam peperangan di Opis pada tahun 539 SM. Seluruh penduduk Babelonia yang sebelumnya tunduk di bawah kepemimpinan Nabonidus, seorang penerus dari Nebukadnezar, tidak memberikan perlawanan yang berarti, bahkan menurut beberapa penemuan sejarah mereka justru menyambut Koresy sebagai seorang pahlawan yang besar dan sebagai seorang hamba yang di utus oleh dewa Marduk. Koresy berhasil masuk dan menduduk seluruh wilayah Babelonia, dan seluruh pemimpin di wilayah yang berhasil ditaklukannya itu mengakui Koresy sebagai raja. Koresy kemudian mempersatukan seluruh wilayah-wilayah hasil taklukannya, miskipun wilayah-wilayah itu berada dalam jangka ruang yang saling berjauhan. Catatan sejarah perjalanan kemenangan Koresy dituliskan pada suatu prasasti batu yang dikenal sebagai silinder Koresy yang isinya memiliki kemiripan dengan isi Yes 45:1. ${ }^{6}$

Kemenangan Koresy rupanya juga menjadi awal kemenangan bangsa Israel dari ketertindasannya. Sekalipun Koresy bukanlah orang Yahudi dan tidak mengenal Yahweh sama sekali. ${ }^{7}$ Juga bukan seseorang yang benar-benar memiliki niat untuk membebaskan bangsa Israel selain daripada berniat untuk perang dengan maksud ekspansi politik, Koresy disebut-sebut sebagai Mesias yang diutus oleh Allah untuk menyelamatkan mereka (Yes 44:8 dan 45:1). Kenyataan ini menunjukkan situasi krisis macam apa dan beratnya tekanan yang dihadapi oleh bangsa Israel pada waktu itu, sehingga orang di luar komunitas mereka pun mendapat keistimewaan diangkat menjadi Mesias yang pada dasarnya jabatan itu telah lama dipahami sebagai jabatan ekslusif yang dimiliki oleh orang berdarah Yahudi sendiri. Dalam masa kejayaan Raja Koresy, mereka benar-benar mendapat kesempatan untuk membentuk identitas ke-Yahudi-an mereka kembali. Setelah sekian lam berada di tanah pembuangan, sekarang mereka kembali ke negeri nenek moyang mereka mencoba membangun kembali komunitas sosial-politik-keagamaan yang selama ini telah tercerai berai. Atas seijin Koresy, mereka dapat membangun kembali Bait Suci yang sebelumnya sempat luluh-lantah.

Katherine E. Southwood dalam Ethnicity and the Mixed Marriage Crisis in Ezra 910: An Anthropological Approach, 2012, menyebut Ezra dan Nehemia adalah dua dari sekian banyak tokoh yang berperan penting selama kepulangan bangsa Israel menuju Palestina sekaligus pembangunan Bait Suci yang kedua, memusatkan perhatian pada pengembalian komitmen ketaatan pada hukum Allah, Taurat. ${ }^{8}$ Seakan ingin meneguhkan pengakuan dan komitmen, serta kesetiaan mereka kembali, bahwa mereka tidak akan

\footnotetext{
${ }^{6}$ David F. Hinson, Sejarah Israel pada Zaman Alkitab, (Jakarta: BPK Gunung Mulia, 2008), 207-208

${ }^{7}$ Emmanuel Gerrit Singgih, Dua Konteks: Tafsir-tafsir Perjanjian Lama Sebagai Respons atas Perjalanan Reformasi di Indonesia, (Jakarta: BPK Gunung Mulia, 2009),36

${ }^{8}$ Katherine E. Southwood, Ethnicity and the Mixed Marriage Crisis in Ezra 9-10: An Anthropological Approach, (New York: Oxford University Press, 2012), 1
} 
mengulangi kesalahan yang sama yang dahulu dilakukan oleh nenek moyang mereka. Mereka yakin bahwa nenek moyang mereka telah melakukan persahabatan dengan dewadewa lain dan orang-orang yang menyembah mereka, akan menghadirkan murka Allah yang berakhir dengan tercerai-berainya komunitas mereka, termasuk apa yang sudah terjadi pada diri mereka selama dibuang ke negeri Babel. Pembuangan ke Babel pertamatama dianggap sebagai sebuah kutuk atau hukuman dari Allah karena perselingkuhan yang nenek moyang mereka lakukan dengan dewa atau penyembahnya, barangkali juga generasi seangkatan mereka saat ini. Sehingga mereka yang menganggap diri mereka masih sebagai umat Allah yang murni dan memiliki kesetiaan.

Setelah pembuangan, bangsa israel kehilangan identitas politik-nasionalisme. Karena kehilangannya, bangsa Israel mengadaptasikan diri dengan berbagai penguasa penjajah (Persia, Yunani dan Romawi) saat itu. Bangsa Israel juga menyadari bahwa pemerintahan raja atau kerajaan cenderung menggunakan kekuasaan untuk menekan rakyat. Rakyat miskin menjadi korban atas kekuasaan politik. Kemusnahan bangsa Israel saat itu tidak membuat bangsa Israel membangun kembali daerahnya yang telah hancur (nostalgia restoratif). Bangsa israel meyakini bahwa hal itu adalah sebuah peringatan bahwa mereka tak boleh lagi membangun ataupun mendirikan suatu negara.

Antara tahun 300-100 SM, muncullah kitab Ester, kisah yang lahir dari konflik orang Yahudi. Kitab ini menceritakan suatu khayalan yang bermaksud untuk menyindir tuntutan dari para penguasa saat itu dan menyindir masyarakat Yahudi sendiri yang ingin bersikap toleran terhadap penguasa. Kitab ini juga menceritakan adanya suatu kutukan yang jelas terhadap setiap penyelewengan kekuasaan politik dan menghancurkan bangsa Yahudi.

Surutnya kekuasaan negara Yudaisme membuat orang tidak terlalu berpikir lagi soal rekonstruksi negara yang baru; sebaliknya mereka hanya mengecam saja kekuasaan politik orang kafir karena mereka berprilaku seperti hewan. Masyarakat jangan menjadi sekte yang tertutup, melainkan terbuka dan siap bekerjasama dengan dunia kafir.

Muncul juga sebuah gerakan revolusioner dari para Makabe. Mereka mencoba mengkonstruksikan kembali suatu negara. Tetapi mimpi mereka diintervensi oleh penguasa romawi. Para makabe berjuang melawan pemerintahan bangsa Seleukos di Syria guna merebut kemerdekaan di bidang politik dan agama. Jalan kekerasan ini diambil Makabe akibat ketidaksetujuaan terhadap pemerintahan raja Antiokius Epifanes yang memerintah seenaknya saja dan berlaku kasar pada orang Israel.

Perjanjian Lama juga menceritakan dan mencari suatu legitimasi terhadap kekuasaan (misalnya pada Mazmur 72). Di balik semuanya itu, Perjanjian Lama ingin menghidupkan suatu idealisme dari suatu masyarakat tanpa negara, tanpa raja, tanpa kekuasaan. Kitab Deuteronomi juga mencoba suatu konsep rekonsiliasi dan konsiliasi antara masyarakat yang asli dan monarkis dan melihat suatu sistem dari pembagian kekuasaan (baik kekuasaan administrasi yuridis, pemerintahan raja, imam, atau para nabi). Pembagian kekuasaan menurut Kitab Deuteronomi adakah sebuah idealisme atau cita-cita yang ingin 
dibangun untuk menterjemahkan Yahweh (Allah) di dalam kehidupan dan struktur negara. Namun tampaknya, negara atau kerajaan tanpa kekuasaan adalah mustahil. Dari Kekuasaan Yahweh kita dapat belajar bahwa kekuasaan adalah membela keadilan dan orang yang miskin.

Banyak gambaran dalam Perjanjian Lama bahwa raja memiliki hubungan dengan yang Ilahi. Hal ini bertolak belakang dengan orang Israel dimana oposisinya adalah insitut monarki, dimana mereka tidak mau mencampuradukkan ketaatannya terhadap agama nasional dan ketaatannya pada negara.

\section{Kritik Profetis Terhadap Kekuasaan}

Perjanjian Lama memiliki kekhasan sendiri yakni adanya kritik profetis terhadap kekuasan politik, ekonomi dan militer. Israel telah mencampuradukkan peran dan kedudukan serta tugas seseorang, dengan contoh seorang nabi mendapatkan fungsi dan kekuasaan yang tinggi. Hal ini tentu tidak betul, karena nabi seharusnya manusia tanpa kekuasaan, independen dan mewartakan sesuatu atas nama Tuhan yang menjadi kekuatannya di dalam tugas pewartaannya itu. Mereka juga harus menolak segala bentuk pemujaan bentuk yang dibuat oleh kekuasan politik, ekonomi dan militer. Mereka juga menolak segala bentuk pemujaan para penguasa karena melawan perintah pertama dari 10 perintah Allah.

Kekuasaan harus merujuk dan harus menjalankan sebuah keadilan, kebenaran, kejujuran dan melindungi orang miskin. Seharusnya, kekuasaan dipakai untuk menghantarkan rakyat berada dalam hidup yang sejahtera.Pemujaan politik menjadi kekhasan bangsa Israel pada masanya. Pemujaan ini adalah forma pemujaan yang paling besar yang sering terjadi di Assyria, Mesir, Babilonia. Pemujaan politik dapat menyingkirkan kekuasaan eksklusif Yahweh pada bangsa Israel, yakni kemampuan untum merawat, menolong dan menyelamatkan umat-Nya. Hal itu digeser dengan banyaknya masyarakat yang mempersonifikasikan dewa-dewi yang disembahnya ke dalam diri raja itu sendiri. Gambaran raja yang benar adalah raja yang merupakan pelayan Yahweh dan kekuasaan yang melekat pada dirinya adalah kekuasan mengembalakan umatnya dan mempersatukan umat agar mereka tetap percaya dan berserah diri pada Yahweh.

Pemujaan politik telah melahirkan persoalan baru yakni adanya ketidakadilan sosial, tindak kriminal. Pemujaan politik secara langsung membuat hukum dan keadilan menjadi diinjak-injak, sehingga lahirlah ketidaktaatan dan kekerasan. Hukum adalah keputusan yang legal yang menjamin kesetaraan, keadilan adalah jaminan akan kemakmuran, perdamaian, kebahagiaan di dalam komunitas tersebut. Memotong dan merusak hukum dan keadilan berarti adalah sebuah pemujaan pada kekuasaan yang merusak dasar hidup bersama.

Para nabi saat itu juga tidak mengusulkan suatu forma yang sederhana akan kekuasaan. Mereka mengajak penguasa untu menghayati kembali semangat solidaritas, yakni kepeduliaan kepada orang miskin. Tak boleh ada penindasan dan penipuan. Kebenaran dan keadilan haruslah diteggakkan. 
Tindakan yang paling nyata dalam Perjanjian Lama adalah tindakan Nabi Hosea, dimana bagi Hosea segala kejahatan terjadi karena adanya sistem monarki atau kerajaan. Mereka memakai kekuasaan untuk alat menindas rakyat. Hosea juga memiliki pemandangan bahwa Allah tak setuju dengan kehadiran monarkis dan tidak setuju dengan tindakan mereka.

Para nabi mengalami ambiguitas kekuasaan , mereka berfikir bahwa kekuasaan tidak bisa diselesaikan begitu saja oleh kehadiran seorang raja ataupun sebuah lembaga pemerintahan karena mereka bukan inkarnasi dari kekuasaan imperal politik. Para nabi selalu mengarahkan bahwa kekuasaan itu akan baik jika membawa kesejahteraan.

Para nabi juga akan mencela segala kekuasaan yang tidak menghadirkan Tuhan. Seperti pada Hosea 8:4, dimana Hosea melawan raja ; Hosea 4:4, melawan imam; Hosea 4:5 , melawan para nabi palsu. Nabi Hosea juga menolak konsep 'vox populi , vox Dei' (suara rakyat, suara Tuhan) karena adanya konsensus yang terjadi diambil karena adanya tekanan pemimpin atau tekanan kelompok lainnya.

\section{Kekuasaan dan kekerasan}

Kekuasaan selalu mengimplikasikan suatu kekerasan yang tegas. Masyarakat politik negara dibangun atas dasar kekuasaan dan menggunakan suatu bentuk kekerasan tertentu yang dimilikinya. Pada umumnya, kekuasaan suatu negara adalah suatu kekerasan yang dilegalkan. Dalam kacamata iman, manusia tidak menganggap dirinya tuan dan karena itu manusia harus menyingkirikan manipulasi dan tekanan dari manusia lain atas nama kekuasaan. Iman kita membenarkan bahwa satu-satunya kekuasaan yang menghidupi dan menyelamatkan yakni kekuasaan Tuhan dan konsekuensi yang logis adalah manusia harus menolak secara radikal setiap kekuasaan.

\section{Pembahasan}

\section{Perkembangan Ekonomi dalam Perjanjian Lama}

Walter Eichrodt menyebutkan bahwa kuasa yang Allah berikan kepada manusia untuk menaklukkan alam semesta mengandung sebuah tanggung jawab. Manusia bukan diberikan hak pakai yang tidak terbatas, baik terhadap dunia binatang maupun tanah. Namun, itu menjadi satu dari tugas-tugasnya untuk menghormati kehidupan. ${ }^{9}$ Allah menciptakan dan menempatkan manusia di dunia adalah sebagai tanda dari otoritas pemerintahan Allah, agar manusia menegakkan dan memperkuat klaim Allah sebagai Tuhan. Karena itu, hal krusial dari manusia sebagai gambar Allah adalah menyangkut fungsinya di dunia. ${ }^{10}$ Dengan demikian semakin jelas bahwa manusia diciuptakan sebagai gambar Allah menunjuk pada sebuah tanggung jawab dalam relasinya dengan Allah dan ciptaan lainnya. Manusia diciptakan sebagai gambar Allah karena perannya selaku penatalayanan atau pelaksana atas ciptaan.

\footnotetext{
${ }^{9}$ Ranto G. Simamora, Misi Kemanusiaan Dan Globalisasi Teologi Misi dalam Konteks Globalisasi di Indonesia (Bandung: Ink Media, 2006), 86.

${ }^{10}$ Ibid, 87
} 
Untuk menilai sudut ekonomi ini, adalah penting mengingat bahwa perekonomian Israel erat kaitannya dengan tanah dan Allah sebagai pemiliknya. Tanah dalam riwayat Israel merupakan pemberian Allah berdasarkan janji kepada Abraham, nenek moyang Israel. Ini merupakan tema utama kelima kitab Taurat, Yosua, kitab para nabi, dan pembangunan kerajaan Daud. Wright sendiri melihat adanya ketegangan yang luar biasa tentang tanah dalam riwayat Israel. Meskipun dalam setiap bagian kitab tersebut sering tidak membahas secara tersirat atau bahkan seolah melupakan janji ini dan menggantikannya dengan cerita perjalanan Israel, hukum dsb, namun tema besar dari kitab-kitab ini adalah tentang tanah.

Dalam perjalanan sejarah, tidak hanya tentang janji tetapi juga tentang pembagian dan cara mempertahankan tanah yang mereka miliki. Tanah juga erat kaitannya dengan persoalan ekonomi. Selain itu, Wright juga menjabarkan beberapa implikasi tentang pembagian tanah sebagai pemberian Allah. Sejak Abraham, Israel merupakan bangsa pengembara. Tanpa Allah, mereka tidak memiliki tanah. Karena itu, pemberian tanah menunjukkan kebergantungan Israel kepada Allah yang mereka andalkan dalam seluruh kehidupan mereka, simbol hubungan Allah dengan Israel, menunjukkan hak kepemilikan pribadi, dan kecaman para nabi karena penghisapan ekonomis.

Israel merupakan umat Allah karena itu tanah diberikan kepada mereka. Sebagai anak Allah, mereka adalah pewaris dari tanah yang dijanjikan. Pemberian tersebut sematamata adalah karya Allah dan dinikmati sebagai berkat dan tanggung jawab moral kepada Allah. Pemberian tanah ini diberikan secara merata kepada semua lapisan masyarakat. Tanah bagi Israel menyangkut masalah identitas. Karena itu, kehilangan tanah bagi Israel tidak hanya menyangkut masalah ekonomi namun juga terhapusnya hubungan dengan Allah. Pemberian ini semata-mata karya Allah dan dinikmati sebagai suatu berkat dan tanggung jawab moral kepada Allah. Menurut Karman, tanah merupakan bukti keterlibatan secara aktif Tuhan dengan Israel. Namun di tanah ini jugalah ajang pergumulan iman bangsa Israel. Tanah diberikan agar Israel memiliki relasi permanen dengan Allah. Allah ingin agar bangsa Israel bergantung sepenuhnya pada Allah. Karena itu kesejahteraan mereka bergantung juga pada relasi yang baik dengan Allah. Sudut ekonomis tanah ini sendiri berperan sebagai termometer rohani hubungan antara Allah dan Israel. ${ }^{11}$

Salah satu sisi ekonomi dalam PL adalah sisi kemiskinan. Alkitab menegaskan realitas kemiskinan dunia. Ulangan 15:11 berkata: "Sebab orang-orang miskin tidak hentinya akan ada di dalam negeri itu; itulah sebabnya aku memberi perintah kepadamu, demikian: Haruslah engkau membuka tangan lebar-lebar bagi saudaramu, yang tertindas dan yang miskin di negerimu." Kebenaran ini digemakan lagi oleh Yesus dalam Matius 26:11, "Karena orang-orang miskin selalu ada padamu, tetapi Aku tidak akan selalu bersamasama kamu." Alkitab mengajarkan respon jasmani terhadap kemiskinan dan

\footnotetext{
${ }^{11}$ Christopher Wright. Hidup Sebagai Umat Allah: Etika Perjanjian Lama. (Jakarta: BPK Gunung Mulia, 1993) 46-62
} 
kelaparan sebagai suatu ujian pengalaman Kristen, kasih sejati dan kebenaran sejati (Yes 58:10; Yak 2:15-17;1Yoh 3:17,18). Untuk mengenal Allah berarti melakukan keadilan untuk orang miskin dan membutuhkan (Yer 22:13-16; Hosea 4:12). Yesus menggenapi perkataan Yesaya yang berbicara mengenai Allah: "Sebab Engkau menjadi tempat pengungsian bagi orang lemah, tempat pengungsian bagi orang miskin dalam kesesakannya" (Yes 25:4).

Pembebasan orang lemah dan orang miskin dari ketamakan orang kuat yang Yesus lakukan ini berpararel dengan tema kunci tindakan pelepasan oleh Allah dalam kitab Yesaya dimulai dengan penghukuman atas ketidakadilan yang timbul dari keserakahan: "Para pemimpinmu adalah pemberontak dan bersekongkol dengan pencuri. Semuanya sukamenerima suap dan mengejar sogok. Mereka tidak membela hak anak anak yatim, dan perkara janda-janda tidak sampai kepada mereka" (Yesaya 1:23). Inilah adalah Firman Allah. Yesus mengajarkan bahwa Allah sangat peduli terhadap orang miskin dan orang yang tidak berdaya. Ia tidak hanya mengajarkannya, tetapi Ia melakukannya juga. Yesus memberi makan orang yang miskin dan yang lapar dan mengajar para murid untuk berbagi dengan orang-orang yang sedang membutuhkan. Ia membawa jalan pembebasan. Kerajaan itu dimulai dalam Yesus. ${ }^{12}$

Pemahaman yang mendalam mengenai ekonomi Israel dengan mempertimbangkan lokasi geografis Israel (di tengah-tengah bangsa-bangsa), sifat dari bangsa-bangsa di sekitarnya, dan pilihan Allah untuk menempatkan Israel dalam situasi seperti itu. Tanah Kanaan di waktu penyelesaian dan pendudukan Israel berada di persimpangan beberapa rute perdagangan dari Mesir ke Mesopotamia (dan, pada tingkat lebih rendah, Asia Kecil). Tuhan memilih untuk menempatkan Israel di tengah-tengah peradaban awal utama. Meskipun bagian timur dari tanah itu dengan topografi yang sangat berbukit, ideal untuk pemukiman. ${ }^{13}$ Wilayah barat sangat mudah diakses secara militer. Dalam hal pengaruh dan serangan budaya dan militer dari luar, Allah menempatkan Israel dalam posisi rentan. Penting untuk mengingat sifat masyarakat sekitar yakni pengaturan feodalistik dan totaliter, dibangun dari kerja para budak dan sangat hierarkis. Agama masyarakat ini biasanya digunakan untuk melegitimasi ekonomi dan politik yang berkuasa. ${ }^{14}$ Meskipun ada sejumlah kesamaan di antara kode-hukum wilayah, juga ada adalah perbedaan penting yang menunjukkan sifat unik Israel. Mengapa Allah menempatkan Israel dalam situasi seperti itu? Alasan yang tak terhindarkan, ditunjukkan oleh Kitab Suci komentarnya sendiri, adalah bahwa Israel dimaksudkan untuk menjadi "terang bagi bangsa-bangsa" (11 Taw. 6: 32-33; Mzm. 15). ${ }^{15}$ Hukum awalnya diberikan kepada Israel, tetapi harus menjadi

\footnotetext{
${ }^{12}$ Glenn H. Stassen dan David P. Gushee, Etika Kerajaan Mengikut Yesus dalam Konteks Masa Kini (Surabaya: Penerbit Momentum), 465

${ }^{13}$ Y. Aharoni, The Archaeology of the land of Israel (Philadelphia: Westminster Press, 1978)

${ }^{14}$ J. Halligan, "The Role of the Peasant in the Amarna Period" in G. MacRae, ed., Society of Biblical Literature: 1976 Seminar Papers (Scholars Press, 1976), 155-69.

${ }^{15} \mathrm{D}$. Van Winkle, "The Relationship of the Nations to Yahweh and to Israel in Isaiah XL-LV Vetus Testamentum XXXV:446-58 (Oct. 1985).
} 
cahaya bagi bangsa-bangsa. Demikian pula Injil diberikan awalnya ke Israel tetapi dipuji untuk semua orang di dunia-sebagai "cahaya untuk bangsa-bangsa lain" (Lukas 2:32; Kisah $13: 47 ; 17: 31)$.

Jika Israel, dan lebih khusus lagi hukum Musa, harus menjadi "cahaya bagi bangsabangsa" Dalam hal struktur sosial-ekonomi Israel pra-monarkis sebagian besar merupakan subsisten, agraris ekonomi dibangun di sekitar komunitas kecil yang terisolasi dan keluarga besar. ${ }^{16}$ Rute perdagangan yang melalui Israel membawanya ke dalam kontak dengan barang dan ide dari seluruh Timur Dekat, dan memfasilitasi spesialisasi yang lebih besar dan pertumbuhan ekonomi yang dicapai di abad ke 8 SM.

Aturan luas yang membatasi negara dan menandai setiap proses peradilan adalah "keadilan dan kebenaran "(I Raj. 10: 9; Mz. 72: 2). ${ }^{17}$ Tetapi ini adalah norma yang luas dan akan membutuhkan jauh lebih banyak spesifikasi konkret dalam praktik nyata dibandingkan dengan aturan tambahan.

\section{Kesimpulan}

Dalam uraian berikut ini, beberapa penerapan norma tambahan ini. Sebuah masyarakat yang adil dan benar akan ditandai oleh:

Pertama, perhatian khusus bagi mereka yang membutuhkan karena keadaan di luar kendali ${ }^{18}$ Tingkat bantuan harus memadai dan perlu; kewajiban kerja bagi mereka yang menerima bantuan masyarakat sesuai (dengan timbal balik kewajiban pengawas komunitas untuk memastikan bahwa ada cukup pekerjaan); seharusnya tidak akan mempermalukan warga miskin ini ketika dalam memberikan bantuan. Prinsipnya, lebih suka bantuan begitu seseorang menjadi miskin.

Kedua, melindungi kebebasan dan menjaga kelayakan ekonomi keluarga besar, baik dari kesulitan ekonomi atau kesewenang-wenangan sosial dan politik. Penugasan hak property terutama ke tangan pribadi (lih. Perintah ke-8) memberikan kesaksian tentang hal ini. Menekankan pentingnya pekerjaan. Tema ini tersirat dalam apa yang disebut "mandat penciptaan" untuk menaklukkan dan menaklukkan, dan secara khusus dibahas dalam Dasa Titah ("enam hari engkau akan bekerja").

Menghormati kontrak dan komitmen. Orang Israel tidak boleh memberikan kesaksian palsu. Transaksi komersial adalah untuk mengetahui bobot dan ukuran yang sebenarnya. Kerusakan yang terjadi akibat tersesatnya ternak karena kelalaian pemiliknya dikompensasi oleh denda yang lebih tinggi daripada jika kelalaian tidak terlibat. Hal ini bukan untuk mengatakan bahwa semua kontrak harus dihormati oleh mereka yang bertanggung jawab untuk mengawasi keadilan.

\footnotetext{
${ }^{16}$ L. Stager, "The Archaeology of the Family in Ancient Israel" BASOR (Bull. of the Amer. Schools for Oriental Res.) 2:601-35 (Nov. 1985)

${ }^{17}$ M. Lind, "Monotheism, Power, and justice: A Study in Isaiah 40-55" Cath. Bib. Quart. 46:432-46 (July 1984)

18 J. Mason, "Biblical Teaching and Assisting the Poor" Transformation 4:1-14 (April/June 1987) 
Penciptaan kekayaan ditafsirkan sebagai kondisi ekonomi yang menghasilkan lebih banyak pekerjaan dan pendapatan yang lebih tinggi. Cara paling ampuh untuk mengurangi jumlah kemiskinan dalam masyarakat berabad-abad adalah dengan menghasilkan pertumbuhan ekonomi yang lebih besar. Hak properti yang stabil dan ditugaskan secara khusus, bersama dengan menghormati pekerjaan secara umum, telah menjadi cara paling efektif untuk mencapai pertumbuhan ekonomi. Mengawasi pengaturan kerja dengan benar dan tingkat produktivitas pekerja yang tinggi (seolah-olah bekerja untuk Tuhan) juga melayani akhir pertumbuhan ekonomi yang kuat. Penempatan geografis Israel memungkinkannya mengambil manfaat dari potensi spesialisasi, dan dengan demikian terwujud pertumbuhan ekonomi yang lebih besar daripada yang mungkin terjadi. Jelas bahwa pencapaian kesejahteraan ekonomi adalah aturan yang dikehendaki Allah dan Torat.

\section{Referensi}

David L. Baker, Mari Mengenal Perjanjian Lama, Jakarta, PT. BPK Gunung Mulia, 2004 LaSor dkk., Pengantar Perjanjian Lama 1, Jakarta, PT. BPK Gunung Mulia, 2002

J.I Packer, Merrill C. Tenney, William White, Jr. Ed., Ensiklopedi Fakta Alkitab II Malang: Gandum Mas, 2001

Rm. Dr. Matius Mali, CSSR, Konsep Berpolitik Orang Kristiani, Yogyakarta: Kanisius Media, 2014

David F. Hinson, Sejarah Israel pada Zaman Alkitab, Jakarta: BPK Gunung Mulia, 2008

Emmanuel Gerrit Singgih, Dua Konteks: Tafsir-tafsir Perjanjian Lama Sebagai Respons atas Perjalanan Reformasi di Indonesia, Jakarta: BPK Gunung Mulia, 2009

Katherine E. Southwood, Ethnicity and the Mixed Marriage Crisis in Ezra 9-10: An Anthropological Approach, New York: Oxford University Press, 2012

Ranto G. Simamora, Misi Kemanusiaan Dan Globalisasi Teologi Misi dalam Konteks Globalisasi diIndonesia, Bandung: Ink Media, 2006.

Christopher Wright. Hidup Sebagai Umat Allah: Etika Perjanjian Lama, Jakarta: BPK Gunung Mulia, 1993

Glenn H. Stassen dan David P. Gushee, Etika Kerajaan Mengikut Yesus dalam Konteks Masa Kini, Surabaya: Penerbit Momentum

Y. Aharoni, The Archaeology of the land of Israel, Philadelphia: Westminster Press, 1978

J. Halligan, "The Role of the Peasant in the Amarna Period" in G. MacRae, ed., Society of Biblical Literature: 1976 Seminar Papers, Scholars Press, 1976

D. Van Winkle, "The Relationship of the Nations to Yahweh and to Israel in Isaiah XLLV" Vetus Testamentum XXXV:446-58; Oct. 1985

L. Stager, "The Archaeology of the Family in Ancient Israel" BASOR (Bull. of the Amer. Schools for Oriental Res.) 2:601-35; Nov. 1985

M. Lind, "Monotheism, Power, and justice: A Study in Isaiah 40-55" Cath. Bib. Quart. 46:432-46; July 1984

J. Mason, "Biblical Teaching and Assisting the Poor" Transformation 4:1-14; April/June 1987 